\title{
(Weak) Institutions for the Advancement of Women: The Case of Women's Policy Agencies in Mexican States*
}

\author{
Instituciones (débiles) para el avance de las mujeres: el caso de los \\ Institutos de la Mujer en México
}

\author{
ALEJANDRA RÍOS CÁZARES \\ Centro de Investigación y Docencia Económicas (CIDE), México
}

\begin{abstract}
This study examines women's policy agencies (WPAs) in Mexico at the sub-national level using four structural variables that the literature has identified as critical: location within the government, mandates, administrative capabilities and leadership. I provide a descriptive inference based on original budget data, human resources and sub-national legislation (2007 to 2014). The data confirm that cross-sectoral mandates may be difficult to fulfill in weak bureaucracies, which supports the proposal that a better strategy might be to build institutions that have a focused mandate. Finally, the Mexican case supports the notion that creating a WPA with a broad mandate and high administrative status that is underfunded may be a low-cost act of legitimacy for governments.
\end{abstract}

Key words: Mexico, women policy agency, advancement of women

\begin{abstract}
RESUMEN
Este artículo estudia los institutos de la mujer a nivel subnacional en México (IM) a partir de cuatro variables estructurales que la literatura ha identificado como claves: ubicación dentro de la estructura gubernamental, mandato, capacidades administrativas, y liderazgo. Se trata de una inferencia descriptiva de los IM basada en información y datos originales sobre presupuesto, recursos humanos y normatividad (2007 a 2014). Los datos sugieren que mandatos intersectoriales son difíciles de concretar en burocracias débiles y apoya la idea de que una mejor estrategia sería construir instituciones con mandatos acotados. Finalmente, el caso mexicano sugiere que la creación de IM con mandato amplio y alto nivel, pero sin recursos, puede ser un acto de legitimidad para los gobiernos en curso.
\end{abstract}

Palabras clave: México, institutos de la mujer, avance de las mujeres 


\section{INTRODUCTION}

A women's policy agency (WPA) is "any structure that meets both of the following criteria: (1) an agency/governmental body formally established by government statute or decree; and (2) an agency/governmental body formally charged with furthering women's status and rights or promoting sex-based equality" (McBride and Mazur 2012: 7). Creating a WPA to address gender equality, problems that are common to women, and the advancement of women began in industrialized countries in the 1960s (True and Mintrom 2001). In other regions, such as Latin America, WPAs did not emerge until the 1980s.

The first Latin American countries to undertake this initiative were Brazil and Costa Rica (1985), followed by Nicaragua and Uruguay (1987). Between 1990 and 1994, eight Latin American countries were added to the list, and Mexico followed in 2001 with the creation of the National Institute for Women (Inmujeres) (True and Mintrom 2001). ${ }^{1}$ Institutional development has been so intense that a significant percentage of countries in the region currently have nationwide WPAs. These organizations sometimes achieve ministerial status (e.g., Brazil, Chile, Costa Rica, Guatemala, Honduras, Panama, Paraguay and Peru), while their position within the bureaucracy in other countries guarantees direct access to the Secretariat of the President's Office or the Central government (e.g., Argentina, Colombia, Ecuador, El Salvador and Mexico). In other situations, WPAs may participate in inter-secretarial coordination forums to craft policy (Colombia) (ECLAD 2004). As of 2011, there were twenty WPAs in Latin America and the Caribbean region (McBride and Mazur 2012).

Empirical analyses of WPAs in industrialized democracies indicate that the main goal of WPAs is to influence policymaking with a goal of introducing a feminist agenda into the debate. However, in developing nations, other approaches posit that a WPA should foster women's issues more broadly than a feminist agenda. During conferences in Mexico City and later in Beijing, the role of the WPA was fully recognized; however, in contrast to the state feminism literature, the Commission defined a WPA as "a body 'recognized by the Government as the institution dealing with the promotion of the status of women'" (Rai 2003: 1-2). In other words, WPAs must educate society about women's circumstances and gender discrimination, design public policies, promote legislation to help improve the status of women, and evaluate government actions related to these topics and the general advancement of women. WPAs are also asked to help consolidate a social and institutional environment that ensures greater participation by women in institutions of political representation and to ensure that this participation has a practical impact (Rai 2003; Franceschet 2007). ${ }^{2}$

In Mexico, however, the antecedent of the National Program for the Integration of Women into Development was established in 1980.

WPAs' "functions were described as, inter alia: supporting the effective participation of women in development; promoting the situation of women in education, political decision making and the economy; ensuring the highest level of government support for this policy; combating negative cultural attitudes and stereotyp- 
WPAs are perceived as important tools for achieving gender equality, which in turn has been recognized as a relevant factor for overcoming endemic poverty (ECLAD 2004). ${ }^{3}$

For these reasons (and expectations), it is important to understand factors that allow these institutions to impact policymaking and the daily work of the government. However, prior to a causal analysis, it is critical to generate better knowledge of WPAs' institutional characteristics. This study examines WPAs in Mexico at the sub-national level to reflect on four structural variables that are identified in the literature as crucial for an effective WPA: strategic location within the governmental structure; the scope of the institutional mandate; administrative capabilities (human and financial resources); and institutional leadership. In other words, this paper does not assess the impact of WPAs on public policies for the advancement of women, nor does it analyze their responsibility in the changes or transformations that have occurred in the status of women in each Mexican state. Assessing the impact of WPAs is a necessary task, but it is a methodological challenge that is beyond the scope of this paper. This study provides a systematic description of WPAs ${ }^{4}$ and thereby seeks to contribute to efforts to understand the role these institutions play-or may play-in the advancement of women in Mexico and middle income countries.

Mexico is an adequate case for a comparative analysis of WPAs for two reasons. First, there have been three decades of efforts to address women's situation and gender equality in the country. Efforts have ranged from updating regulations to creating an institutional structure that aims to protect both women's rights and the principles of gender equality. Albeit at different rates, similar changes have occurred at the federal level and in state and municipal governments. ${ }^{5}$ Each Mexican state has an institutional design that is based on the separation of powers and is an autonomous regime within a federal arrangement. This characteristic indicates that each state created a WPA in its own time and under specific circumstances. Thus, Mexico provides an opportunity to compare WPAs that were created more than twenty years ago (e.g., the state of Guerrero's WPA) with institutions that have been created recently (e.g., the state of Veracruz's WPA); and all within the same historical and cultural context.

The Mexican case is also interesting because the last fifteen years included intense activity in institutional reform and legislative adjustments for gender equality, in which WPAs were and continue to be key actors. Two recent reforms

ing of women in the media; facilitating research on the status of women; and collecting sex disaggregated data" (Rai 2003: 1-2).

3 For example, this is the primary argument of the USAID Policy on Gender Equality and Female Empowerment. Accessed January 31, 2016. https:/ /www.usaid.gov/sites/default/files/documents/1865/GenderEqualityPolicy_0.pdf

4 See King, Keohane and Verba (1994) for an explanation of differences between descriptive and causal inference. This paper presents a descriptive inference.

5 Mexico is a federal regime that is composed of thirty-two state governments and 2457 municipal governments (indeed, the official name of the country is the United States of Mexico). 
are notable examples: In 2006, the Federal Congress passed the General Law for Equality between Women and Men, which mandated the creation of the National System for Equality between Women and Men (in operation since May 2007). This legislation delegated the coordination of federal government agencies to the National Institute for Women (Inmujeres) and mandated the National Human Rights Commission to oversee the operation of the system. Moreover, this legislation mandated that all state governments must create corresponding systems in their territories. Thus, similar to changes at the federal level, every state system is coordinated by its corresponding WPA. Subsequently, in 2008, the Federal Congress enacted the General Law on Women's Access to a Life Free of Violence, which facilitated the construction of statewide protection programs that significantly involve all thirty-two state WPAs. ${ }^{6}$

In short, past decades have seen considerable efforts to advance a gendered perspective in policy. While these innovations are welcome, it is not clear whether the key institutions that were designed by the Mexican state have the resources to meet the challenges of the new (and old) responsibilities that these changes entail.

This analysis demonstrates that Mexican WPAs face serious challenges to having their voice heard in governmental decisions and that there is doubt about the viability of their mandate. The primary conclusion is that WPAs' location within the government structure does not guarantee their capacity to influence the decisions of state governments (as demanded by the paradigm of gender mainstreaming, one of the guiding principles for gender equality). The data also indicate that the resources provided for WPAs does not correspond with the mandate imposed on them by state constitutions and regulations. Despite the status that state legislations provide to WPAs, the constraints that are documented in this paper suggest that WPAs in Mexico restrict their role in policy to a consultative body at best. This situation directly points to state governments' commitment to their own WPAs and to the goal of achieving effective gender equality.

To support this analysis, I developed a database of the thirty-two sub-national WPAs in Mexico using three sources of information. First, I submitted 128 informational requests that asked the thirty-two sub-national WPAs about their budgets, human resources and the basic characteristics of the history of their WPA directors. ${ }^{7}$ My information requests targeted both the WPAs and the state legislatures. I submitted and processed a first round of requests between the fall of 2012 and the spring of 2013 and a second round in 2014-2015 (only two states

See the General Law for Equality between Women and Men (Ley General de Acceso de las Mujeres a una Vida Libre de Violencia). Accessed April 4, 2017. http://www.diputados.gob.mx/LeyesBiblio/pdf/ LGIMH_240316.pdf; see also the General Law on Women's Access to a Life Free of Violence. Accessed April 4, 2017. http://www.diputados.gob.mx/LeyesBiblio/ref/lgamvlv/LGAMVLV_orig_01feb07.pdf It is important to highlight that Mexico has an advanced Freedom of Information statute that requires all public offices to respond to information requests by citizens or provide an answer for the absence of data. 
were unable to provide information: Baja California Sur and Tamaulipas). ${ }^{8}$ Second, I reviewed budget decrees and expenditure reports. Third, I reviewed all applicable state legislation that established the mandate and scope of WPAs in Mexican states.

The data that support my analysis include a complete time series of the approved budget for 25 of the thirty-two Mexican WPAs, with 75\% of this information for three additional WPAs and $63 \%$ of this information for two more WPAs. These data allow me to present a comparative analysis for thirty of the thirtytwo Mexican WPAs across an eight-year period (2007-2014). ${ }^{9}$ The data are from primary sources; therefore, these data avoid one of the principal weaknesses in comparative analyses of WPAs in developing countries: opacity regarding the source of information and the use of secondary sources (MacBride and Mazur 2011).

This article is organized into four sections. First, I present a brief literature review of the main factors that impinge upon WPAs' effectiveness. Second, I present the development of WPAs in Mexico, which is followed by an analysis of the data. Finally, I reflect upon the gathered information.

\section{FOUR DETERMINANTS OF WPAS' EFFECTIVENESS}

There is consensus in the literature on WPAs for one conclusion: It is not possible to identify a unique factor (or group of factors) that improves the likelihood that a WPA will be effective in advocating for a women's agenda (or the feminist agenda) in the debate and the policy process. Instead, empirical analyses of WPAs in postindustrial democracies conclude that the influence of a WPA on key policy issues is the result of equifinality-when different combinations of variables lead to the same outcome (McBride and Mazur 2012: 16). ${ }^{10}$ However, this conclusion results from comparative analyses of WPAs in industrialized democracies, and, as the main authors of this research contend, there are factors specific to industrialized democracies that are not directly applicable to other realities, such as those in developing nations. I am aware of and concur with the argument that some assumptions in this literature are not amenable to other settings; however, I also argue that there is a core set of variables that remain significant, regardless of the context. ${ }^{11}$ Specifically, I refer to structural variables,

8 To know more about freedom of information in Mexico, see the country profile of Freedominfo.org. Accessed January 31, 2016. http://www.freedominfo.org/regions/latin-america/mexico/mexico2/

9 I excluded WPAs from two states in the analysis (Coahuila and Tamaulipas), as it was impossible to obtain any data regarding their budgets. The primary database will be available after the review process is completed. The database is hosted at the National Lab of Public Policies databank with full open access.

10 For a definition of equifinality, see Mahoney and Goertz (2006).

11 Valiente (2007) elaborates a nuanced critique about the limitations of the literature on WPAs to understand WPA in developing nations, while Bohn (2009) provides an interesting critique based on the Brazilian experience. For a rebuttal see MacBride and Mazur (2011). 
such as strategic location, the scope of the mandate, administrative capabilities, and institutional leadership.

I am aware of the critical limitations of studying structural variables. The most significant challenge is that these variables only reflect the structural characteristics of WPAs and not their actual performance. However, I believe that these variables are key factors that affect the likelihood of institutional success; in other words, these variables "should be conceptualized as potential factors, conditions, influences or drivers in explaining the outcomes of agency activities" (McBride and Mazur 2012: 25), and the picture I depict in these pages is a first and necessary step towards a causal analysis of the actual impact of WPAs on policy outcomes. ${ }^{12}$

The first variable refers to a convenient governmental hierarchy. As such, a WPA must have political and institutional resources-such as a central, strategic location within the government structure-to ensure free access to the major players in decision-making processes (Teghtsoonian and Chappell 2008; McBride and Mazur 2012). For example, a strategic location might require that the institution is subject to the direction and supervision of the Executive, such as a secretariat of state, which would allow it to participate in cabinet meetings and thus expand the possibility that it might influence the general decisions of the Executive branch (Franceschet 2007). However, belonging to the cabinet is not the only alternative. Authorities from several institutions in Latin America also posit that a strategic location has "access to decision-making circles, to coordination bodies and to inter-sectoral commissions" (ECLAD 2004: 78).

Second, a WPA must have a broad mandate that allows it to influence general planning processes and the creation of public policies, rather than a limited mandate and/or a mandate that targets specific policy areas (e.g., reproductive health or providing assistance for women victims of violence) (Teghtsoonian and Chappell 2008). For instance, a planning secretariat has a broader mandate because it involves all governmental policies and/or offices. Third, a WPA should have administrative capabilities, which refers to sufficient financial and human resources to support the actions requires to enforce their legal mandate. A lack of sufficient material and institutional resources limits the impact of an organization-regardless of its hierarchical level within the government.

Fourth, a WPA should have strong political and bureaucratic leadership. The directors of any WPA must have proven authority among the network of social organizations and within the state bureaucracy. The director must seek ideological alignment between government departments and the institution's organizational stability. Leadership with these characteristics is only obtained

12 A comprehensive literature review about the comparative analysis of WPAs can be found in McBride and Mazur (2012). In this piece, the authors clearly explain the limitations of structural analysis for establishing causal conclusions about the role of WPA in policy making. I am aware of these limitations, but still believe that having a clear assessment of institutional characteristics is the first step towards a causal analysis of how WPAs affect policy outcomes. 
through continuity in office and a recognized career in public administration (Teghtsoonian and Chappell 2008).

These factors are mutually reinforcing; thus, having a strategic location does not guarantee effective operation, but being in a peripheral position in decision-making circles, undertaking a limited mandate, and/or lacking the necessary material resources ensures that these institutions will have a much weaker influence (Teghtsoonian and Chappell 2008). Similarly, the likelihood of a WPA's influence on policy decisions will be greater when the legitimacy of the institution is recognized in the state bureaucracy to the extent that it has mechanisms that enable it to enforce its specific, yet broad, mandates.

\section{THE DEVELOPMENT OF WOMEN'S POLICY AGENCIES IN MEXICO ${ }^{13}$}

In Mexico, discussions about the need for WPAs began in the late 1970s in response to the resolution of the First World Conference on Women (held in Mexico City in 1975) and the work of organized social movements, such as the Broad Women's Movement (Caminos posibles 2007). ${ }^{14}$ At the national level, the effort toward institutionalization stalled in the years that immediately followed the 1982 economic crisis as a result of the drastic consequences of the economic imbalance and because of the priorities of the two presidents who were in power during the 1980s. First, President Miguel de la Madrid Hurtado (1982-1988) adopted a restricted view that reduced all federal policies for women's issues to birth control (Lang 2003; Caminos posibles 2007). Then, President Carlos Salinas de Gortari (1988-1994) focused on a single government program that was aimed towards "the development of projects that promote women's selfemployment and productivity" (Caminos posibles, 2007: 16) $\cdot{ }^{15}$ By the end of the 1990s, President Ernesto Zedillo Ponce de León (1994-2000) changed this course and established the National Women's Program (1995-2000) and a Coordinating Office that led to the creation of the National Women's Commission, which was the predecessor of the National Institute for Women (Inmujeres), created in January 2001 during the government of Vicente Fox (2000-2006). ${ }^{16}$

At the sub-national level, institutional development has followed a different path. Despite some isolated events, it was not until after the first world conference that specific institutional responses gradually began to emerge. ${ }^{17}$

13 In Spanish, these agencies are known as Instancias de la Mujer en las Entidades Federativas, for which a direct translation would be Institutes for Women in the States; however, their logic and rationale are similar (or the same) as the State Agency for the Advancement of Women or what is known as Women's Policy Agencies and Women's Policy Machines.

Movimiento Amplio de Mujeres.

Women in Solidarity Program (Mujeres en Solidaridad).

See Lang (2003) for a review of this decade and the political history behind the creation of Inmujeres.

Such as the Tamaulipas Institute for Women, established in 1962, or centers that provided support for victims of sexual violence in Tabasco and Mexico City in the early 1980s (Quintero Ramírez 2009). In the state of 
During the late 1980s and early 1990s, there was a slow appropriation of the idea that focusing on women was a matter of public concern and required state intervention. However, the impetus for creating WPAs at the local level did not occur until the late 1990s.

In 1997, the state of Querétaro established the State Council for Women, and, in 1998, the states of Colima, Sonora, and Quintana Roo created their respective state agencies. Between 1999 and 2000, another 10 states incorporated WPAs into their administrations. In 2001, the year of the inception of Inmujeres, seven more states created WPAs. Nonetheless, it was not until 2007 that every state in the country had an institution of this nature. Therefore, sub-national WPAs in Mexico are, on average, more than 14 years old. The oldest WPA is the Guerrero Secretariat for Women (1987), while the youngest is the Veracruz Institute for Women (2007) (Table 1). ${ }^{18}$

Table 1: Year of inception and institutional age

\begin{tabular}{lccc}
\hline \multicolumn{1}{c}{ State } & Acronym & Year of inception & Institutional age \\
\hline Guerrero & GRO & 1987 & 28 \\
Querétaro & QRO & 1997 & 18 \\
Colima & COL & 1998 & 17 \\
Quintana Roo & QROO & 1998 & 17 \\
Sonora & SON & 1998 & 17 \\
Baja California Sur & BCS & 1999 & 16 \\
Michoacán & MIC & 1999 & 16 \\
Puebla & PUE & 1999 & 16 \\
Tlaxcala & TLAX & 1999 & 16 \\
Zacatecas & ZAC & 1999 & 16 \\
Chiapas & CHS & 2000 & 15 \\
Durango & DGO & 2000 & 15 \\
México & MEX & 2000 & 15 \\
Oaxaca & OAX & 2000 & 15 \\
Sinaloa & SIN & 2000 & 15
\end{tabular}

Colima, the State Institute for Women continued the work that was started by the Griselda Alvarez Center for Women's Support (CAM), which was created by the Governor of the state of Colima Griselda Alvarez in 1983 (Caminos posibles 2007).

18 According to Caminos posibles (2007), the creation of the Institute for Women in Nayarit in 2004 completed this list. However, the data provided by the WPAs in response to the information requests indicate that that the state of Veracruz did not create the State Institute for Women until 2007 (although it had a State Program for Women since 1999). Notably, I present data on the formal creation of state institutes for women, which does not necessarily mean an absence of governmental responses to women's issues and / or gender equality, as shown in the case of Veracruz. 


\begin{tabular}{lccc}
\hline \multicolumn{1}{c}{ State } & Acronym & Year of inception & Institutional age \\
\hline Aguascalientes & AGS & 2001 & 14 \\
Baja California & BC & 2001 & 14 \\
Campeche & CAM & 2001 & 14 \\
Coahuila & COA & 2001 & 14 \\
Guanajuato & GTO & 2001 & 14 \\
Jalisco & JAL & 2001 & 14 \\
Tabasco & TAB & 2001 & 14 \\
National & & 2001 & 14 \\
Chihuahua & CHH & 2002 & 13 \\
DF & DF & 2002 & 13 \\
Hidalgo & HGO & 2002 & 13 \\
Morelos & MOR & 2002 & 13 \\
San Luis Potosí & SLP & 2002 & 13 \\
Yucatán & YUC & 2002 & 13 \\
Nayarit & NAY & 2003 & 12 \\
Nuevo León & NLEON & 2003 & 12 \\
Tamaulipas & TAM & 2005 & 10 \\
Veracruz & VER & 2007 & 8 \\
\hline
\end{tabular}

Source: author's information requests and state legislation.

The age of a WPA is more than just a curious statistic, as institutional stability is vital when one of the central duties of the institution is to achieve social change. However, similar to any government agency, sub-national WPAs have undergone significant changes in recent years. Some of these transformations consolidated WPAs' positions within the administration (as stated in the literature), while others have limited their scope and reach. Two examples of the former transformations include the transition of the State Council of Women of the state of Querétaro into the Querétaro Institute for Women (2011) and the transformation of a WPA into a Secretariat (or ministry). This was the case for the states of Michoacán (2008), Chiapas (2010), and, more recently, Coahuila and Zacatecas (2012) (see Table 2 for a summary of institutional changes between 2007 and 2014).

There are also examples of what is considered a "setback" in the literature, such as the transformation of the State of Mexico Institute for Women (IMM) into the State Council for Women and Social Welfare. This amendment added the task of monitoring the state policy for the elderly onto the IMM's original responsibilities. ${ }^{19}$

19 The reform required that the new institution "plan, implement, coordinate and evaluate the actions to provide assistance for this sector of the population", which referred to the elderly. Moreover, the Government 
The reform required the new institution to "plan, implement, coordinate and evaluate the actions to provide assistance for this sector of the population", and refers to the elderly. In practice, the reform of the IMM has meant that government intervention "[oscillates] between the expansion of social benefits that respond to the needs and risks of social protection and others, which are far fewer, designed to expand the areas of women's power and participation" (Guadarrama Sánchez 2010: 89). ${ }^{20}$

The case of the IMM exemplifies the relevance of institutional stability, for which the characteristics undergirding the creation of a WPA are a determining factor. For instance, a WPA that is created by legislative decree is generally more stable than a WPA that is created by executive decree, at least in presidential regimes. ${ }^{21}$ Notably, the IMM was created and transformed by executive decrees, which is common in Latin American (and presidential) countries (Franceschet 2007). ${ }^{22}$

Decree established that "[t]his determination will allow a single organization to promote, with a comprehensive perspective, actions of support for women and the elderly, in order to integrate them into everyday life with the greatest possible number of resources to provide prosperity and a better quality of life" (México 2006).

20 Guadarrama Sánchez (2010: 78) also documents how the reform recovered "traditional contents that perceive women as recipients of social benefits and include types of intervention that are not conducive to mainstreaming with an orientation that affects the causal factors of inequity and discrimination against the female population."

21 The legal act of creating a WPA matters for one simple reason: the greater the number of actors with decision-making (or veto) power that are involved in the institutional design of a WPA, the greater the stability of the final decision. See Tsebelis (2002) for an introduction to veto player theory. Tarres (2007) also highlighted this problem.

22 For an explanation of the difference between legislative and executive decrees, see Carey and Shugart (1998). 
Table 2: Institutional transformations of Mexican WPAs (2007-2014)

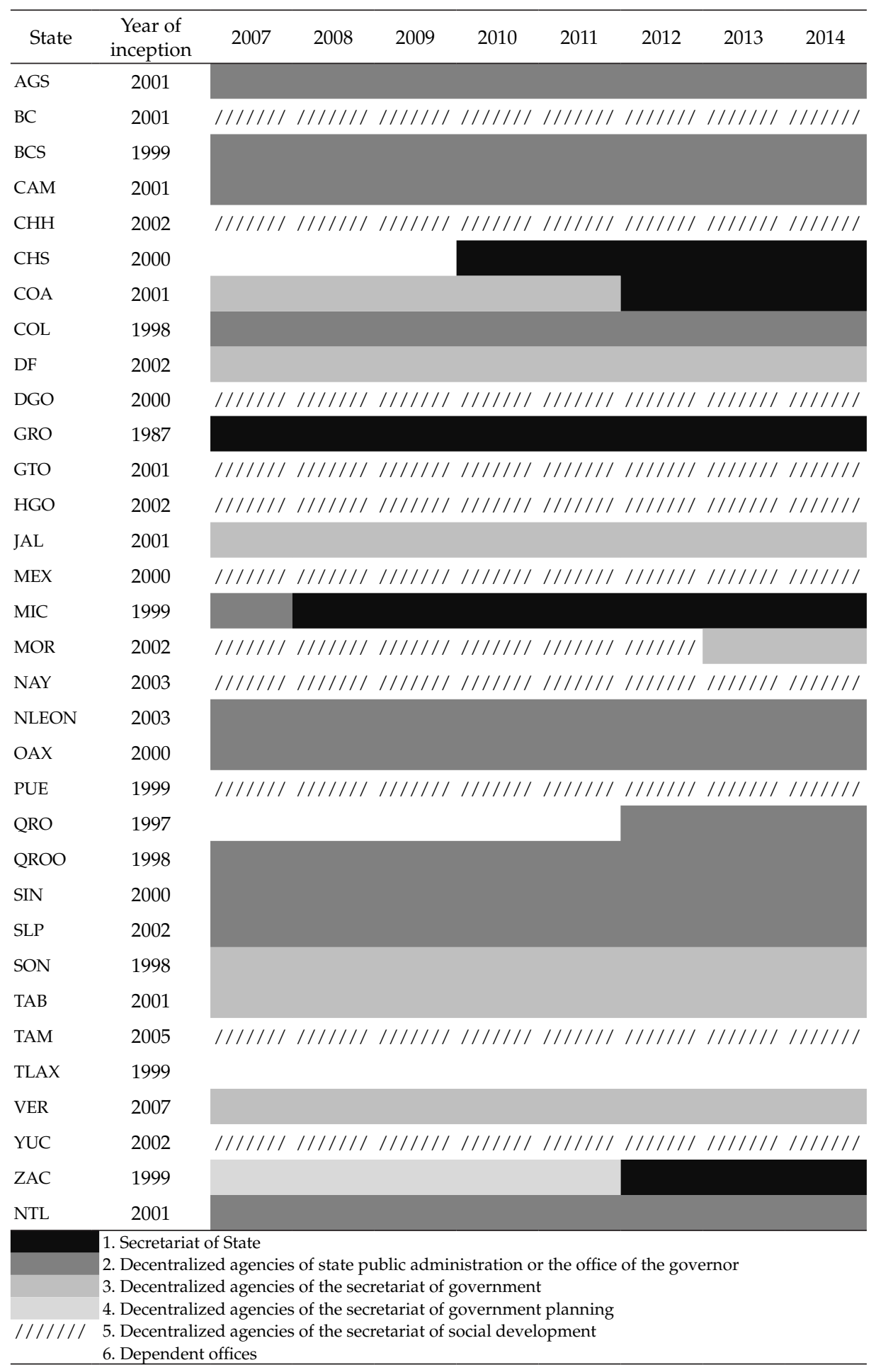

Source: author's information requests and state legislation. 
From this perspective, Mexico has a positive situation: there are now thirtytwo government agencies at the sub-national level with state jurisdiction whose primary purpose is the advancement of women (with the exception of the State of Mexico, where the mandate of the institution is not exclusive to women). Moreover, the majority of these organizations were created by legislative decree, which ensures a certain degree of institutional stability (Tarres 2007), and the most recent reforms have improved the administrative status of these institutions. This depiction suggests a promising situation for the advancement of women in Mexico. However, the central question is whether these institutions are legally and structurally prepared to meet the challenges that are posed by the consolidation of gender equality, the advancement of women, and the implementation of the "new" paradigm of gender mainstreaming in a developing nation with an entrenched culture of machismo. The data in the following sections suggest that there is unfinished business for consolidating the institutional potential of these government agencies.

\section{A PICTURE OF MEXICAN WPAS}

\section{Strategic Location}

Mexican public administration is organized into two distinct types of institutions: centralized and decentralized agencies. Agencies in the centralized structure depend directly on the executive office (i.e., secretariats), and state legislation determines their realm of influence (competence). To meet government goals, either the executive or the legislature can create decentralized agencies that depend on a specific secretariat or the executive office. The goal of these decentralized agencies is to discharge centralized public administration from new tasks or functions, but only within the realm of action that the law has defined for the secretariats (Roldán Xopa 2008). Decentralized offices typically have administrative capacity and some autonomy from their parent secretariats.

Secretariats can also have another type of agency, known as a "dependent office," which does not have administrative autonomy from its parent secretariat. The goal of these offices is to streamline the management of specific activities. Because there is no direct translation into English for these two types of agencies, but there is a difference between them, I refer to the first as "decentralized agencies" and the second as "dependent offices." Therefore, for the purpose of this paper, I distinguish between a secretariat, a decentralized agency, and a dependent office.

In Mexico, this difference in the administrative status of a WPA determines its "strategic location." Secretariats have a much broader scope of action than decentralized or dependent offices. For example, although most WPAs' responsibilities include adapting legislation, only secretariats can draft bills, decrees, and regulations for the issues that are within their competence. 
Secretariats can also publish "circulars, agreements and administrative decrees relating to their realm of action, which, due to their legal nature, does not need the signature of the State Executiveor a legislative process for their formalization [...]". To facilitate their work, secretariats may create dependent offices that are tasked with intervening in the planning, programming and budget proposals within their sphere of competence. In contrast, decentralized and dependent offices remain under the umbrella of the secretariats. In sum, a WPA's realm of influence wanes as it moves its strategic location from secretariats to decentralized to dependent offices.

In 2014, it was possible to distinguish among three groups of WPAs in Mexico. First, one group of WPAs in 2014 were secretariats (Chiapas, Coahuila, Guerrero, Michoacán and Zacatecas). At the opposite extreme, the WPA in Tlaxcala is a dependent office. In between, there are WPAs that are decentralized agencies; however, there are significant differences within this subgroup. A WPA that is a decentralized agency of the State Public Administration has, at least, de jure, a broader range of influence than other agencies because its immediate and ultimate supervisor is the governor of the state (the head of the executive) and not a specific secretariat. There were 10 such WPAs in Mexico in 2014. There are also WPAs that are decentralized agencies of the Secretariat of Government, whose sphere of influence is statewide and involves all realms of public policy. This group includes six WPAs. The remaining 10 WPAs are decentralized agencies of the Secretariat for Social Development, whose scope is limited to welfare policy and poverty reduction programs. Thus, a decentralized agency of a Governor's office is a more strategic location than a decentralized agency whose immediate superior is the head of a secretariat.

Mexico has a wide range of WPAs in terms of strategic locations. One expectation of this variance is that WPAs must differ according to these institutional characteristics, both in their scope of action and in the availability of resources. However, as I show in the following sections, this is not the case: Most of the time, the mandate exceeds their "bureaucratic authority" and challenges their scarce resources.

\section{WPA Mandates}

The literature does not elaborate on the legal and administrative capabilities that are necessary for a WPA; however, WPA's primary purposes include the ability to influence policymaking to incorporate a gender perspective, actions regarding gender equality, and/or to incorporate women's issues or a feminist agenda into the public debate. These goals stipulate that any WPA should have the legal and institutional means to affect policy design. Thus, to influence decision making, it is reasonable to propose that WPAs should be involved in all (or at least some) of the five essential stages of policymaking. First, there is the planning stage, which determines the strategies, guidelines, 
and courses of action for any policy. Second, the programming stage focuses on translating planning goals into operational programs. The third stage, budgeting, involves quantifying the human and financial resources that are required for ensuring the successful implementation of the programs that were established during the programming stage. After defining the programs and resources, the next step is implementation, which is followed by the final stage, which is devoted to evaluating the policies and programs.

To determine WPAs' mandates, I reviewed all current legislation as of December 2014. On average, a Mexican WPA has 22 specific legal responsibilities or attributions. The highest number is for the WPA in Quintana Roo (a decentralized agency of the state government), and the lowest is for Nayarit (a decentralized agency of the Secretariat of Social Development). I classified each mandate or attribution according to one of the five policy stages that were previously mentioned.

Specifically, 50\% of WPAs are entitled to participate in planning either directly, such as through directing state planning subcommittees, or indirectly, such as by encouraging the gender perspective in public policies (Figure 1). For example, $78 \%$ are required to design the State Plan for Women or the State Plan for Equality between Men and Women (or its equivalent). This occurs even when the WPA's jurisdiction is constrained to social development. WPAs are also involved in two central activities for public policy planning: $25 \%$ of WPAs must assess the circumstances of women in the state, while $44 \%$ must create, manage and coordinate statewide information systems, such as those for violence against women in the state. Clearly, both functions involve a strong capacity for coordination with other public administration agencies.

For programming, $75 \%$ of WPAs must implement measures that incorporate the logic of gender mainstreaming into the state public administration, while $50 \%$ must design policies that have a gender perspective. For budgeting, the secretariats (Chiapas, Guerrero, Michoacán, Coahuila and Zacatecas) have the greatest influence on submitting a budget proposal, which may include the series of programs and actions that will be implemented in their jurisdiction. However, this proposal is subject to approval from the Secretariat of Finance and the state legislature. More than half of WPAs can manage contributions from the federal government, international organizations, and civil society organizations and channel these funds into the interior of the state. Given the lack of state resources, WPAs tend to depend on external funding (Ríos Cázares 2013).

WPAs are also entitled to influence the implementation of public policy. For instance, $47 \%$ of WPAs are required to implement the State Plan for Women or the State Plan for Equality between Men and Women (or its equivalent). Again, this is a complicated task for those WPAs whose jurisdiction is delimited to the realm of social development. Finally, for policy evaluation, $41 \%$ of WPAs must assess women's policies, and 31\% must issue periodic assessment reports. 
Most of the legal responsibilities for any WPA relates to specific tasks, such as advising municipal governments $(63 \%)$, serving as a consultative, training and advisory body for other government agencies $(63 \%)$, and promoting the adjustment of all legislation (69\%). A notable result of this analysis is the absence of legal provisions that enforce planning or oversight activities.

Figure 1: WPAs' legal attributions

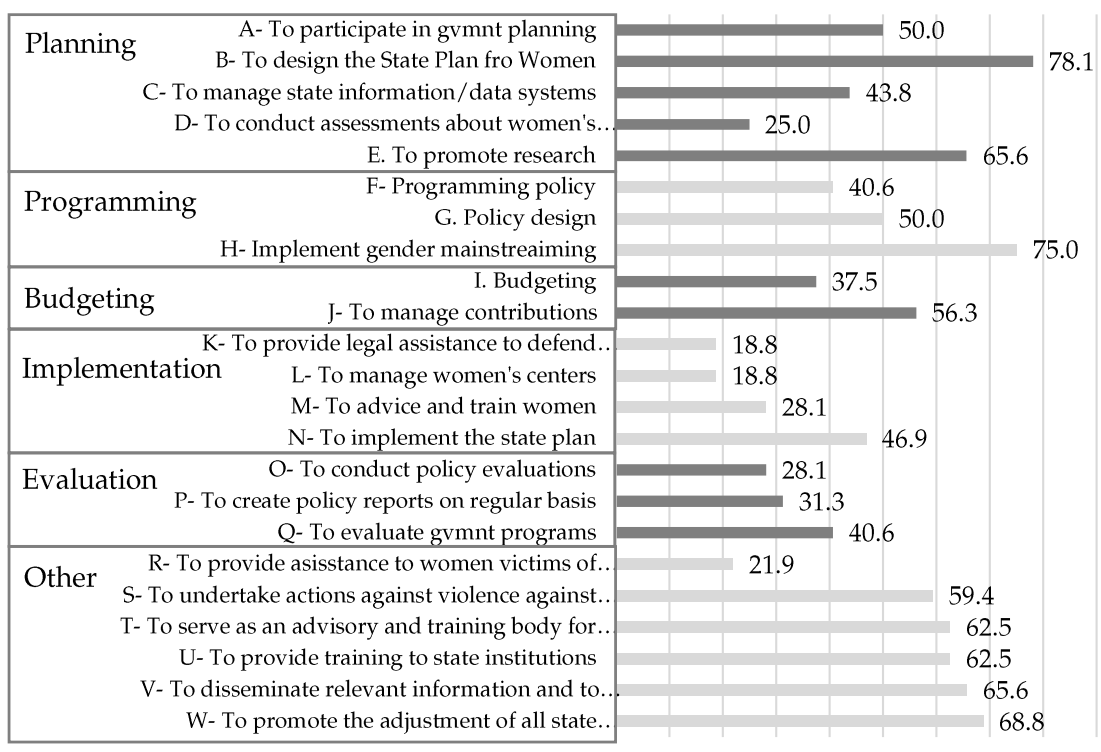

$\begin{array}{lllllllllll}0.0 & 10.0 & 20.0 & 30.0 & 40.0 & 50.0 & 60.0 & 70.0 & 80.0 & 90.0 & 100.0\end{array}$

Source: State legislation current for 2014

Specific examples of the responsibilities of a WPA are as follows. A WPA is involved in the "implementation of public policies to promotenon-discrimination and equality between men and women" (Aguascalientes, decentralized agency of state public administration).$^{23}$ It also addresses public policy design and evaluation, "with a gender perspective to allow equality between men and women" (Tabasco, decentralized agency of the secretariat of government). ${ }^{24}$ WPAs are also in charge of promoting the "comprehensive development of women and their full participation in the economic, social, political, cultural and familiar life of the state [...]" (Chihuahua, decentralized agency of the Secretariat of Social Development), ${ }^{25}$ and are responsible for achieving greater inclusion of women in the educational and professional realms. Moreover, WPAs must meet categorical goals, including the design of public policy for addressing specific 
problems, such as those of "single mothers, especially [...] women who become pregnant at an early age" and/or the development of programs "for women who engage in prostitution" (Campeche, decentralized agency of the State Public Administration) ${ }^{26}$

As shown, the strategic locations of sub-national WPAs within state administrations are heterogeneous; however, the breadth of their legal mandate tends to be ample and uniform. This analysis indicates that regardless of their strategic location or scope of influence, all Mexican WPAs must take action in all policymaking stages and different policy areas. Therefore, the strategic location is not correlated with specific tasks; in other words, state governments have created different institutions to do similar or almost equivalent activities. An important question is whether WPAs have sufficient resources for successfully fulfilling their responsibilities and reflecting their administrative hierarchy, or whether their financial and human resources can compensate when their positioning is not particularly strategic.

\section{Administrative Capabilities}

Determining the correct amount of resources that a WPA should receive is an analytical exercise that exceeds the scope of this document. However, it is clear that an institution whose realm of action involves all areas of public administration and all stages of policymaking must have a professional civil service and consistent access to financial resources. In this section, I compare the financial and human resources that are available to Mexican WPAs. The data are weighted by the size of the state's total budget with the goal of creating an indicator of the state government's effort to endow WPAs with sufficient resources.

Figure 2 shows the WPAs' budget as a percentage of the state budget between 2007 and 2014, with the states placed in ascending order by average. The purpose of the figure is to present variations in the budget rather than detailed information. This figure shows that the allocation of budgets is relatively stable across states during the time period. ${ }^{27}$ Notably, in 14 states, the budget that was assigned in 2007 was greater than that in 2014 despite nationwide reforms that were approved in 2007 that assigned a central role in fighting gender violence against women to every WPA in the country.

Law of the Campeche Institute for Women, Art.7, sections XXIII and XXIV.

An alternative indicator could have been the annual per-woman budget for the period under analysis. This comparison demonstrates that WPAs' budgets are typically stable (the coefficient of variation is higher than one only for Chiapas). Indeed, there are states in which budget allocation has been virtually the same over the past five years (State of Mexico) despite variations in the total female population in the state. 
Figure 2: WPA budget as percentage of state budget (2007-2014) (ascending order by average)

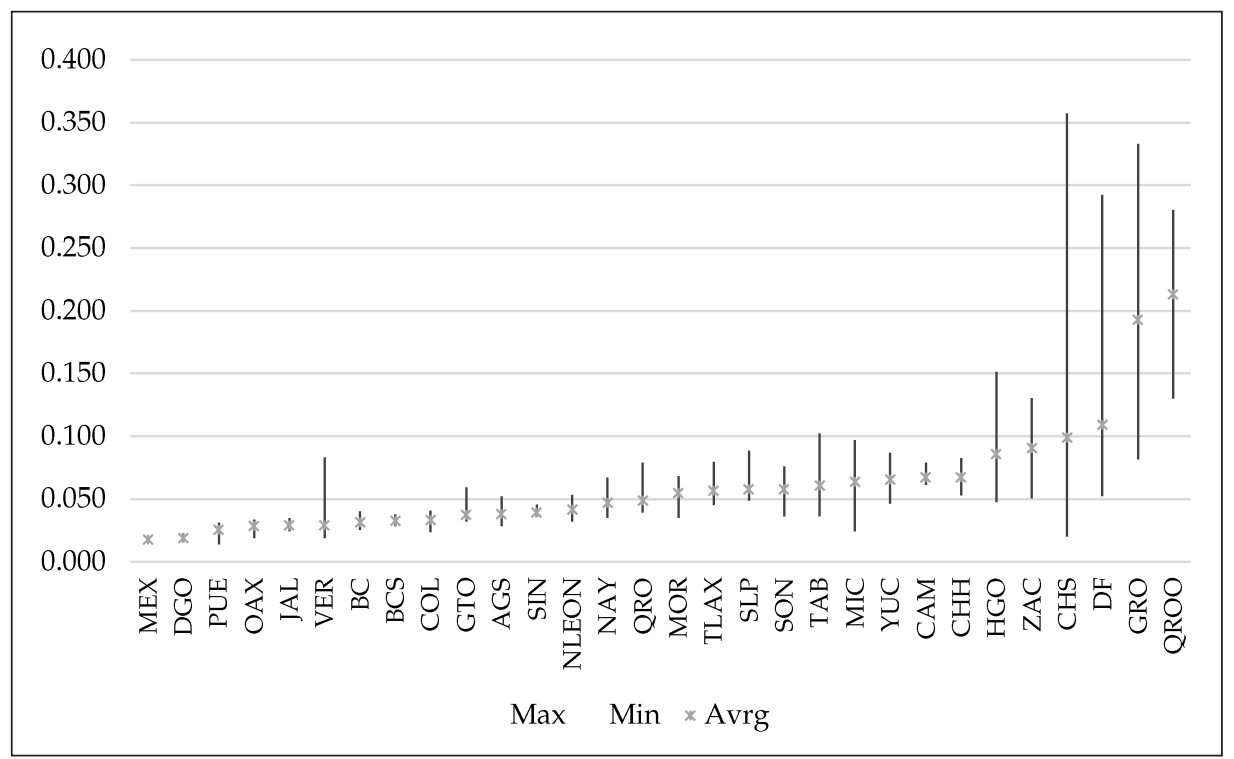

Source: author's information requests, budget decrees and expenditure reports.

Theoretically, budgetary allocation should respond to the strategic location of WPAs within the hierarchy of the state public administration. However, the available data indicate that there is no systematic variation between institutional characteristics and budget distribution. In fact, budget allocation is counterintuitive: the WPA in Quintana Roo is a decentralized agency of the Executive, and it received higher budget allocations (with regard to the total state budget) than the secretariats of Guerrero and Michoacán from 2007 to 2011. In contrast, the WPA in Tlaxcala (the weakest WPA in the country in terms of strategic location for the entire period) is higher than 16 WPAs when the average for the period is taken into account.

Resources from state government are scarce; however, there is an alternative source of funds. According to testimonials from WPA personnel, federal resources constitute a major portion of WPA resources. ${ }^{28}$ Two federal funds provide financial resources to WPAs. The first and most relevant is the Program for the Support of Institutes for Women in the Federal States (PAIMEF) of the Social Development Institute (Indesol). PAIMEF's main goal is to reduce violence against women. ${ }^{29}$ The second source is the Federal Fund for Strengthening

28 The author conducted semi-structured interviews with WPA staff on actions to reduce violence against women in late 2012 and early 2013 (Ríos Cázares 2013).

29 Indesol is an agency that is dependent on the Social Development Secretariat at the federal level. For more about the program, see (accessed January 31, 2016) http://www.indesol.gob.mx/es/web_indesol/Programa_de_Apoyo_a_las_Instancias_de_Mujeres 
Gender Mainstreaming of the Inmujeres. ${ }^{30}$ Access to these funds is not equivalent or secure for all WPAs because funding is related to specific projects. Notably, WPAs that are better staffed and equipped tend to be the most successful in competing for funding.

The influence of external funding is clearly reflected in the characteristics of the WAPs' staff. As mentioned, a professional civil service is essential for any governmental institution, but it is critical for an institution whose main responsibilities include analyzing and assessing women's situation in the state, as well as providing services that require specialized personnel.

The available information for 2014 (27 out of 32 WPAs) indicates that, on average, WPAs have 110 employees, of which $31 \%$ are politically-appointed positions, ${ }^{31}$ $19 \%$ are core staff and 50\% are temporary workers. Temporary employees often depend on external resources (such as federal funds). In five states, temporary staff account for $50 \%$ or more of the total personnel (Baja California, Durango, México, San Luis Potosí and Tabasco), although the state of Mexico is an extreme case, with $92 \%$. If we add temporary employees and contract staff, the percentage increases to $68 \%$ for Oaxaca and $88 \%$ for Chihuahua. In sum, there is high vulnerability in personnel stability for WPAs; in other words, there is no professional civil service whatsoever (Figure 3).

30 Known as Programa de Fortalecimiento a la Transversalidad de la Perspectiva de Género (PFTPG) Accessed January 31, 2016. http:/ / www.gob.mx/inmujeres/acciones-y-programas/fortalecimiento-a-la-transversalidad-de-la-perspectiva-de-genero.

31 The phrase "politically appointed employees" refers to employees who "are subject to special treatment in the Law, these are employees holding a position of confidence who perform managerial, accounting, operational, supervisory functions on behalf of their employer. They may not belong to trade unions and may be discharged if they lose the confidence of their employer, without the right to be reinstated in their job" (SCJN 2010: 346). 
Figure 3: WPA staff

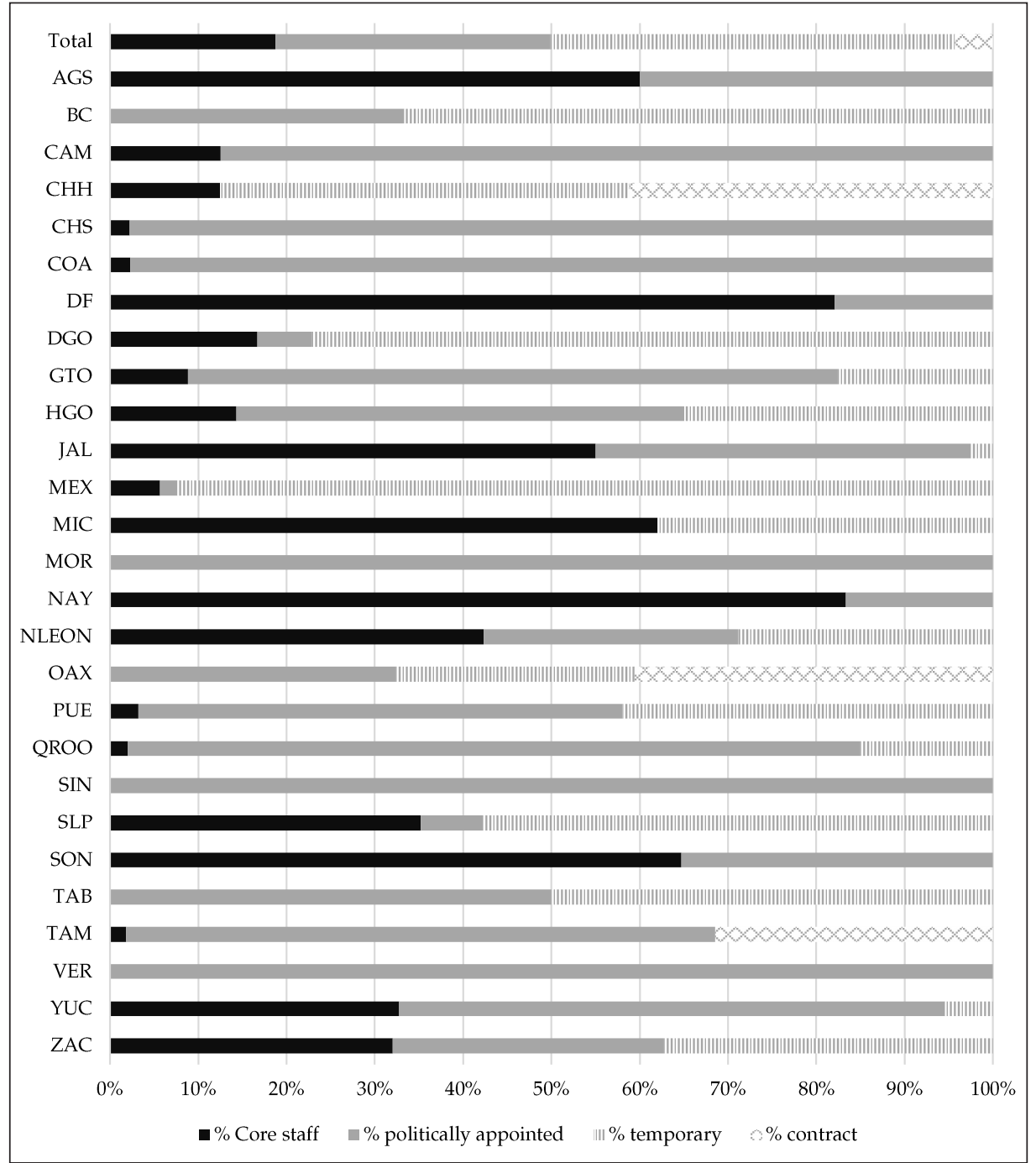

Source: author's information requests.

An example of how a lack of resources impacts institutional capabilities is demonstrated in the efforts of the Hidalgo Institute for Women to ensure the continuous operation of 17 regional service offices-each with a lawyer and a psychologist-that assist women there. These offices operate with funds from PAIMEF, and, although they have been successful in expanding health care coverage, they must reduce or suspend activities in the three months that federal resources take to become available at the beginning of the fiscal year. Consequently, like civil society organizations, WPAs are forced to seek 
alternative measures to support services, and the continuity of activities is often achieved through the efforts of a committed staff. ${ }^{32}$

The situation of the Hidalgo Institute for Women reflects the budget pressures facing WPAs: insufficient resources creates the potential danger of restricting work to specific policies, thereby renouncing the aim to mainstream. It reduces their capacity to influence overall planning processes and therefore, once again, limits the possibility of consolidating the logic of equality in government work.

A final factor that merits attention is the stability of WPA leadership, which affects the ability of these agencies to influence decision-making. I approximate the stability of a WPAs' leadership by examining the frequency of change at the director level and assume that a continuous rotation leads to an institutional inability to adopt, adjust, and consolidate work schemes. ${ }^{33}$ This is particularly important in governmental institutions-as in Mexico-in which a change of director implies an imminent change of all politically-appointed personnel and, as a result, the entire staff.

There is accurate information on the tenure of each WPA director in 31 states (in 14 of these cases, the data encompass the entire history of the WPA). According to these data, on average, the director of a WPA remains in office for 36 months (the executive term in Mexico lasts six years or 72 months). When only using the data from the 14 states with complete information, the average increases by seven months. In four cases, the last director of the WPA remained in office for 72 months, which corresponds to a six-year governmental period (Baja California Sur, Chihuahua, Durango y Guanajuato).

The full significance of these data is apparent when noting that many actions that WPAs must undertake to perform their functions require coordinating with other government agencies (such as intervening in planning discussions or coordinating information systems) combined with an extensive knowledge of state public administration, both of which directly depend on professional experience.

To present a comprehensive comparative perspective of the information, Figure 4 depicts a transformation of four variables (strategic location; the scope of mandate; human and financial resources) into 0-1 indicators that have been averaged to create one comprehensive index. Per this ranking, the best WPA in Mexico would be in the state of Quintana Roo, while the worst would be in the state of Tlaxcala. The ranking appears to be concomitant to non-systematic assessments and perceptions about the role of WPAs in public policy. For example, the Quintana Roo Institute for Women (IQM) stands out from the rest, given its strong institutional development that is reflected in successfully

32 Interview conducted by the author with personnel from the Hidalgo Institute for Women (gender equality, gender rights, legal counseling and psychological support offices). May 29, 2012.

33 Measuring leadership is a task that demands careful qualitative methodology to analyze the experience of the director and the achievements of the institution under his or her command. 
constructing municipal delegations since the time of its inception (1998) and because it has managed to ensure their continued presence throughout the state's territory even when local governments have created municipal women's institutes. This success can be attributed to 19 years of operation that have allowed IQM delegations to be "better identified by the population than [the municipal institutions themselves]." The institutionalization of IQM is reflected in the "degree of maturity of the delegations," which "are clear about their responsibilities and [their] basic function [the main] part of their work [being] the administration of federal funding and the supervision of projects in municipalities" (Rodríguez 2009: 369, 370).

Figure 4: Summary ${ }^{34}$

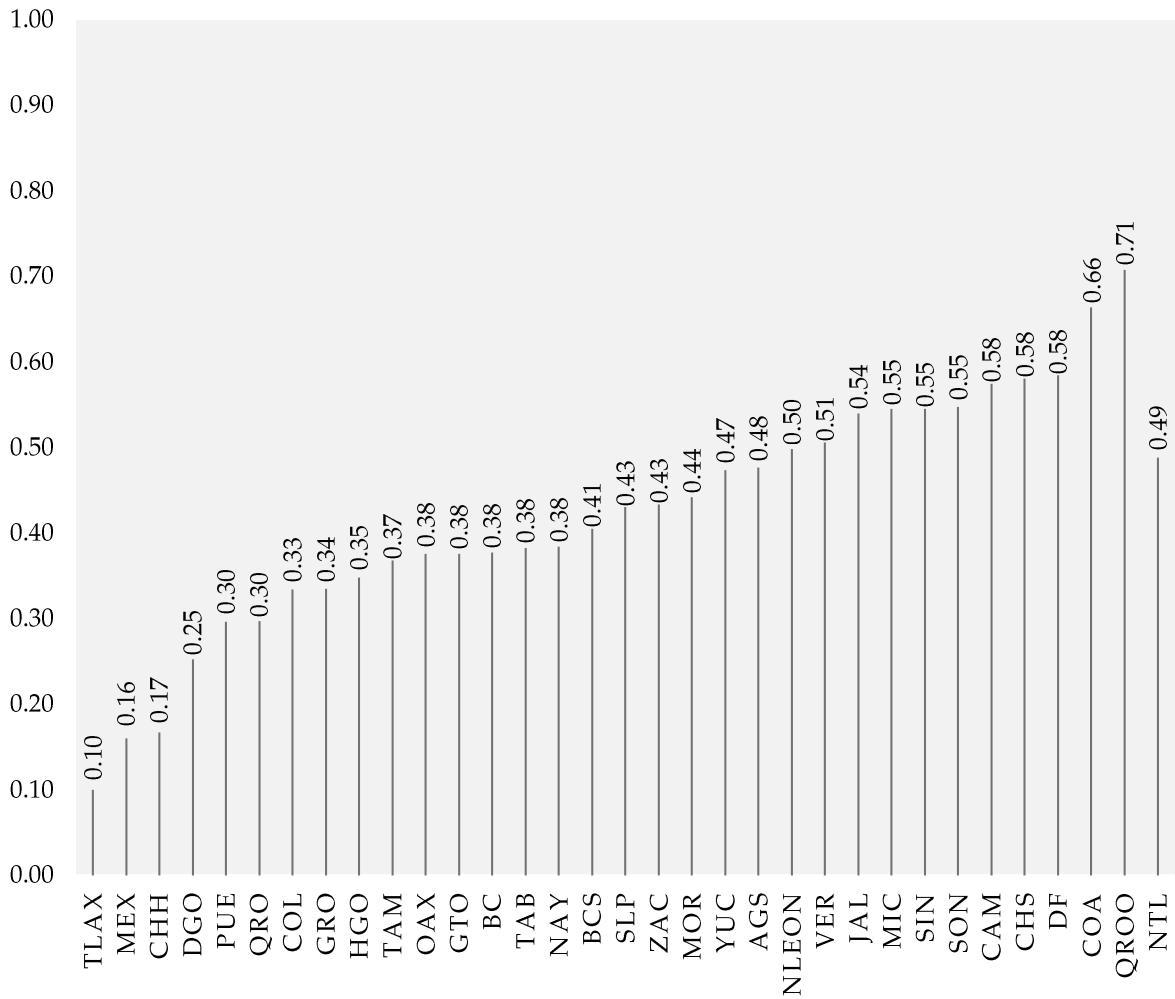

34 For this figure, I normalized the outcome of each variable as 0-1. For strategic location, I employed a scale of 1 to 6 depending on the strategic location of each WPA and then normalized the outcome to 0-1; for mandate, I normalized the outcome using the highest number of responsibilities that were mandated by law (55); for human resources, I add temporary and contract workers and then divided by 100 to standardize the index as $0-1$. The outcome for each state is the average of these four measures. 
At the opposite extreme, the State of Mexico's WPA appears to be an example of an institutional setback, as explained above. Moreover, examining these results through the issue of violence against women in Mexico-one of the policy areas in which WPAs devote most of their efforts given the source of their resourcesthere is a clear correlation: the worst-situated WPAs come from states in which violence against women and femicides are-or seem to be-unstoppable. ${ }^{35}$

In sum, the variables that I have analyzed (strategic location, mandates, resources and directorship) delineate the institutional status of WPAs in Mexico. These data, however, do not exhaust an analysis of the factors that affect the consolidation of WPAs as bureaucratic leaders for the advancement of women, although they provide empirical characteristics.

\section{CONCLUSIONS}

The advancement of women and gender equality are two central issues in a country's development. Thus, government intervention is essential for helping remove the barriers that women face in escaping the cycles of poverty that cause unequal access to all types of public services. WPAs are part of this government response. In Mexican states, there are many WPAs in the government sphere that are protected by unanimous votes in local Congresses and have the support of the incumbent governor, who often endorsed or promoted their creation. Organized movements for women's rights across the country participated in different ways and with varying degrees of intensity in constructing these institutions, which promised a new style of government intervention in solving age-old problems of inequality and discrimination. We should appreciate the fact that all Mexican states currently have a government agency for the advancement of women. However, 27 years after the first WPA was created in the state of Guerrero, it is worth considering whether these institutions are legally empowered and financially able to further the consolidation of an egalitarian society. The indicators that were constructed from Mexican WPAs' features and resources do not suggest a particularly optimistic outlook. ${ }^{36}$

The available data confirm that not all variables are equally significant (supporting the notion of equifinality for the comparative analysis of WPAs). The results indicate caution for at least two variables. First, the strategic location

35 Tlaxcala is internationally known for having growing organized crime that is devoted to sex slavery and forced prostitution; the state of Mexico recently declared a "gender alert" due to the increasing number of homicides where the victims are women and Chihuahua is also internationally known for the case of Caso Algodonero or Muertas de juárez. For the State of Mexico, see the National Citizens Observatory of femicides (Observatorio Ciudadano Nacional del Feminicidio http://observatoriofeminicidiomexico.org.mx/) and regarding the Gender alert, see http://www.alertadegenero-edomex.com/. About Tlaxcala, see the HSTC Intelligence Report of October 28, 2010 https://www.state.gov/documents/organization/151384. pdf All documents were last consulted on April 4, 2017.

36 Indeed, the State of Guerrero (one of the poorest states in Mexico) is a good example: It is among the worst in the country for the situation of women, but its WPA has been a secretariat of the state since 1987 and it has been among the wealthiest WPAs for the past nine years. 
is not fundamental because the responsibilities that Mexican legislations confer on WPAs tend to be similar, despite their bureaucratic hierarchies within the government structure. Second, any advantage from a strategic location is lost when a WPA lacks mechanisms to enforce its decisions. This is particularly important because most of a WPA's responsibilities include coordinating other state agencies to incorporate gender mainstreaming in all areas of policy. Therefore, despite having a legal mandate to undertake an ample scope of action, the absence of mechanisms that bind WPAs' resolutions reduces their influence on policy to making recommendations, which suggests that their success depends on persuasion (ECLAD 2004).

Thus, holding resources constant, transforming a WPA into a state secretariat does not automatically lead to greater influence, at least in Mexico. The Mexican case supports the notion that cross-sectoral mandates may be "impossible to fulfill" from the very beginning. It also supports the idea that a better strategy for the advancement of women in countries that face a wide array of priorities and limited resources might be to build institutions that have a focused mandate and compensate by creating committees for gender equality within each governmental agency (Valiente 2007).

The financial data I present also suggests that Mexican WPAs are another example of institutions that are unable to comply with their legal mandates. In a developing nation, the lack of resources is a typical constraint; for a WPA, the main consequence of this situation is significant institutional vulnerability in two ways. First, the greater a WPA's dependence on external resources, the greater the channeling of its time and staff to implement activities that should fulfill the demands of the funding agencies (primarily federal), which, in turn, constrains long-term planning. Second, this dependence on external funding may explain the high reliance of WPAs on temporary staff, which leads to an institutional dilemma: to be able to operate, a WPA must limit its activities to a few policy areas and abandon the broad mandate that was conferred by the state legislation.

This general picture of WPAs in Mexico and the situation of Mexican women supports the notion that creating a WPA that has a broad mandate and high administrative status, but is underfunded, is a low-cost act of legitimacy for state governments (Adams 2007). There are two initial consequences of this situation. On one hand, WPAs will never fulfill their mandate; on the other hand, weak WPAs may become neutralizers of civil society organizations and feminist advocates. ${ }^{37}$

The Mexican case also posits several questions that are related to WPAs in developing nations (and federal regimes) that await sound answers. For example, is there a systematic effect of federalism on sub-national WPAs? Under 
what circumstances can federalism promote or constrain policy innovation (Chappel and Curtin 2012)? What, if any, is the influence of a powerful federal government on policy decisions for women at the state level? How do we evaluate these institutions?

There are high expectations for the role of WPAs in reducing gender inequality, which is one of the most acute reasons for endemic poverty in developing nations. However, reality demonstrates that there is a long way to go to consolidate institutions that are capable of incorporating a gender perspective as a guideline for government action; the "new form of governance" that is needed by women in developing nations (Jacquot 2010). The situation of Mexican WPAs also invites reflections on the best strategies of government intervention for the advancement of women in middle-income nations.

\section{REFERENCES}

Adams, Melinda. 2007. "National Machineries' and Authoritarian Politics." International Feminist Journal of Politics 9 (2): 176-197.

Alonso Alvarez, Alba, Isabel Diz Otero, and Martha Lois González. 2010. “La influencia de las políticas públicas de igualdad en la toma de decisiones: un análisis de los informes de impacto de género." Revista Española de Ciencia Política 24:107-136.

Bohn, Simone R. 2009. "Bridging State and Civil Society? The Amphibious Nature of 'State Feminism' in Brazil." Paper presented at the annual meeting for the Society of American Political Science Association, Toronto, Canada, September 3-6.

Caminos posibles, Investigación Capacitación y Desarrollo S.C. 2007. Fortalezas, debilidades, oportunidades y amenazas de las políticas y programas contra la violencia familiar en los institutos e instancias de la mujer en México. Mexico City: Instituto Nacional de Desarrollo Social, INDESOL.

Carey, John M., and Matthew Soberg Shugart. 1998. Executive Decree Authority. Cambridge: Cambridge University Press.

Chappel, Louise, and Jennifer Curtin. 2012. "Does Federalism Matter? Evaluating State Architecture and Family and Domestic Violence Policy in Australia and New Zealand." Publius: The Journal of Federalism 43 (1): 24-43.

Economic Commission for Latin America and the Caribbean, ECLAD. 2004. "Roads Towards Gender Equity in Latin America and the Caribbean." 9th Regional Conference on Women in Latin America and the Caribbean, Mexico City, May.

Franceschet, Susan. 2007 “From Persuasion to Power? Women's Policy Machineries in Latin America" Paper presented at the Women in the Americas: Paths to Political Power Conference, New York, NY, March.

Guadarrama Sánchez, Gloria Jovita. 2010. "El enfoque de género y la agenda de gobierno. Una aproximación al proceso de institucionalización en el Estado de México." Cofactor 1 (2): 75-93.

Jacquot, Sophie. 2010. "The Paradox of Gender Mainstreaming: Unanticipated Effects of New Modes of Governance in the Gender Equality Domain." West European Politics 3 (1): 118-35.

King, Gary, Robert O. Keohane, and Sidney Verba. 1994. Designing Social Inquiry: Scientific Inference in Qualitative Research. Princeton, NJ: Princeton University Press

Lang, Miriam. 2003. “¿Todo el poder? Políticas públicas, violencia de género y feminismo en México." Iberoamericana - América Latina - España - Portugal. Ensayos sobre letras, historia y Sociedad III (12): 69-92. 
Mahoney, James, and Gary Goertz. 2006. "A Tale of Two Cultures: Contrasting Quantitative and Qualitative Research." Political Analysis 14 (3): 227-249.

McBride, Dorothy, and Amy Mazur. 2012. "Gender Machineries Worldwide." In World Development Report. Gender, Equality and Development. Washington, DC: World Bank.

México, Estado de. 2006. “Decreto del Ejecutivo del Estado por el que se modifica el diverso por el que se crea el organismo público descentralizado de carácter estatal denominado Instituto Mexiquense de la Mujer." Gaceta del Gobierno. Accesed January 31, 2016. http://cemybs.edomex.gob.mx/sites/cemybs.edomex.gob.mx/files/files/GACETA\%2017_\%20DECRETO\%20DE\%20CREACION.pdf

Rai, Shirin M. 2003. "Introduction." In Mainstreaming Gender, Democratizing the State? Perspectives on Democratization, edited by Shirin M Rai. Manchester: Manchester University Press.

Ríos Cázares, Alejandra. 2013. Sistemas de Información de los ministerios públicos con perspectiva de género. Informe nacional. México: INMUJERES-CIDE. Accessed December 5, 2017. http://www.mexicoestatal.cide.edu/wp-content/uploads/2016/06/Informe-Nacional.pdf

Rodríguez Castillo, Luis. 2009. "Diagnóstico a instancias municipales responsables de la instrumentación de las políticas de igualdad entre mujeres y hombres. Región Sureste." In Instancias municipales de la mujer en México., edited by Comisión Nacional de Derechos Humanos. México: Comisión Nacional de Derechos.

Roldán Xopa, José. 2008. Derecho Administrativo. Mexico: Oxford University Press.

SCJN, Suprema Corte de Justicia de la Nación. 2010. Political Constitution of the United Mexican States. Mexico: SCJN.

Tarres, María Luisa. 2007. “Nuevos nudos y desafíos en las prácticas feministas: Los Institutos de la la Mujer en México." In Políticas Sociales y género. La institucionalización, edited by Gisela Zaremberg. Mexico: FLACSO.

Teghtsoonian, Katherine, and Louise Chappell. 2008. "The Rise and Decline of Women's Policy Machinery in British Columbia and New South Wales: A Cautionary Tale." International Political Science Review 29(1): 29-51.

True, Jacqui, and Michael Mintrom. 2001. "Transnational Networks and Policy Diffusion: The Case of Gender Mainstreaming." International Studies Quarterly 45 (1): 27-57.

Tsebelis, George. 2002. Veto Players: How Political Institutions Work. Princeton, NJ: Princeton University Press.

Valiente, Celia. 2007. "Developing Countries and New Democracies Matter: An Overview of Research on State Feminism Worldwide." Politics \& Gender 3 (04): 530-541.

\section{Legislation}

General Law for Equality between Women and Men. Accessed January 31, 2016. http:/ / www. diputados.gob.mx/LeyesBiblio/pdf/LGIMH_040615.pdf

General Law on Women's Access to a Life Free of Violence. Accessed January 31, 2016. http:/ / www.diputados.gob.mx/LeyesBiblio/ref/lgamvlv/LGAMVLV_orig_01feb07.pdf

Organic Law of Public Administration of the State of Chiapas

Organic Law of Public Administration of the State of Michoacán de Ocampo

Organic Law of Public Administration of the State of Chiapas

Organic Law of Public Administration of the State of Guerrero

Law Creating the Aguascalientes Institute for Women

Law of the Tabasco Institute for Women

Law of the Chihuahua Institute for Women

Law of the Campeche Institute for Women

Alejandra Ríos Cázares is Professor-Researcher at the Public Administration Divison of the Centro de Investigación y Docencia Económicas (CIDE), Mexico, and a member of Mexico's National Researchers System. She holds an MA and PhD in Political Science from the University of California, San Diego. Her research interests focus on subnational institutions, accountability, transparency, and gender violance. Email: alejandra.rios@cide.edu 
